\title{
Antioxidants: good, bad or indifferent
}

\author{
Shaun McCann ${ }^{1}$
}

Received: 30 October 2018 / Accepted: 30 October 2018 / Published online: 14 November 2018

C) Springer Nature Limited 2018

'...for a bottle of good wine, like a good act, shines ever in the retrospect...'

Robert Louis Stevenson (1850-1894) Scottish novelist, poet and travel writer.

Antioxidants and their putative beneficial effects on health have been in the medical news for as long as I can remember. Antioxidants act as 'free - radical scavengers'. Free radicals can cause cell damage and may contribute to cancer and cardiovascular disease. According to the National Cancer Institutes of the U.S.A. (NCI), there is no evidence that antioxidant supplements, taken as pure chemicals, reduce the incidence of cancer, however this does not totally negate the possibility of a protective antioxidant effect when consumed as 'foods'. Whether antioxidants can prevent or reduce the incidence of cardiovascular disease is hotly disputed.

In 1991 a popular TV program, 60 minutes, hosted a debate on the 'French Paradox' a term first used by a French scientist Serge Renaud. The 'paradox' describes the apparently low incidence of coronary heart disease in the wine-drinking French population in spite of a diet rich in saturated fats. Whatever about the actual benefits of drinking red wine, consumption in the USA shot up by $44 \%$ the following year. Interestingly a long article in the International New York Times in the summer of 2018 discussed the benefit of the so-called' Mediterranean diet' and never mentioned red wine!

R. Corder and colleagues from Queen Mary's School of Medicine in London [1] claim to have isolated oligomeric polycyanidins from red wine in concentrations which could be beneficial to health and specifically arterial disease. They postulate that moderate consumption of red wine is linked

Shaun McCann

shaunrmccann@gmail.com

1 Trinity College, Haematology Emeritus, University of Dublin, Dublin, Ireland to a reduced risk of CHD and lower overall mortality. They identified procyanidins as the principle vasoactive polyphenols in red wine and showed that they are present at higher concentrations in wines from southwestern France and Sardinia. These regions are associated with increased longevity in the population where traditional production methods ensure that these compounds are efficiently extracted during vinification.

Ikarians (off the west cost of Turkey) live ten years longer than the average European and are two-and-a-half times more likely to reach 90 years of age than an American [2]. The University of Athens Medical School is investigating the reason for this longevity, but in the meantime Theodosis, a 67-year-old local retired chef, had his own explanation:' Many Ikarians make their own wine and drink a glass every day. They drink it carefully, mixing it with water in a tradition that goes back to the classical symposiums. It's to make people talk'

Another potent antioxidant polyphenol, resveratrol, is thought to work as an anti-aging substance by activating the gene SIRT1. The pharmaceutical company GlaxoSmithKline (GSK) bought the company Sirtis for $\$ 720$ million in 2008 because the company had a formulation of resveratrol known as SRT501. Unfortunately, clinical trials were stopped in 2010 because it was very difficult to maintain adequate drug levels and the drug was associated with dehydration and renal insufficiency. Luis Espinoza [3] and colleagues have extensively reviewed resveratrol and although it has many interesting effects on cell lines in hematological malignancies its clinical use cannot be recommended at present. Its notorious variability in bioavailability makes it difficult to evaluate and 'optimum formulations ...require further study.'

Some intriguing research suggests that resveratrol can increase the synthesis of $\mathrm{Hb} \mathrm{F}$ in vitro. It is possible that it could increase the synthesis of $\mathrm{Hb} \mathrm{F}$ in vivo thus alleviating some of the symptoms associated with Sickle Cell Disease and the Thalassaemic syndromes [4].

Resveratrol is significantly a component of wine and the Japanese giant knotweed ( $h u$ zhang in China) Ko-jo-kon, an 
<smiles>Oc1ccc(/C=C/c2cc(O)cc(O)c2)cc1</smiles>

Fig. 1 Resveratrol found on the skin of red grapes

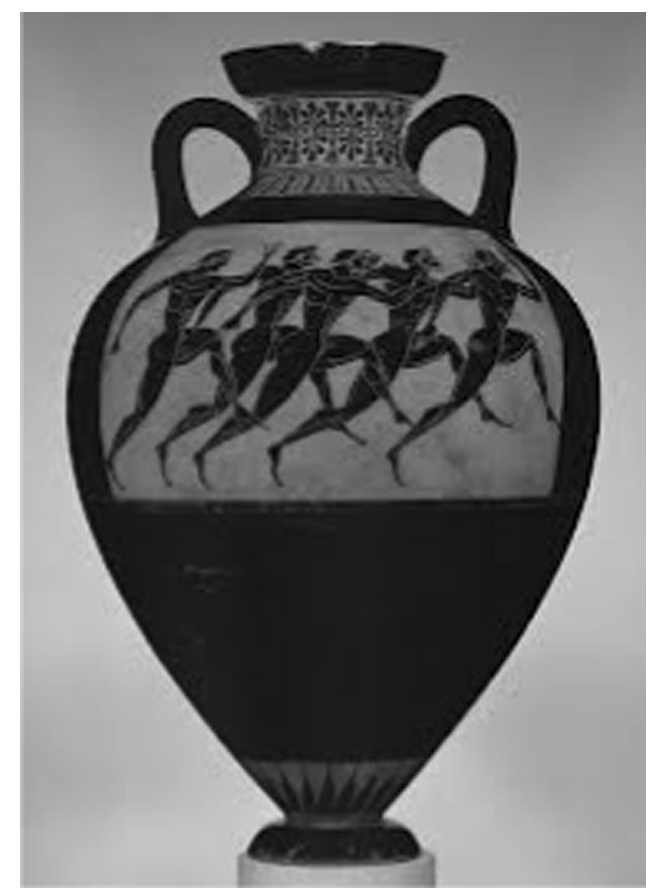

Fig. 2 Amphora used to transport wine in ancient Greece. Some were highly decorated oriental natural medicine used to treat diseases of the blood vessels, heart, and liver. It is found on the skin of red grapes and is probably produced by fungi which colonise the grape skin. It may protect from heart disease but the daily amount of wine required to provide a protective effect would probably induce severe liver damage thereby negating any putative benefit. Jacob Gaffney, writing in the Wine Spectator drinks a glass of Cabernet Sauvignon every night but also takes resveratrol supplements daily. Maybe Gaffney is right but I'll stick to my nightly glass of red wine (Figs 1, 2).

\section{Compliance with ethical standards}

Conflict of interest The author declares that he has no conflict of interest.

\section{References}

1. Corder R, Mullen W, Khan NQ, Marks SC, Wood EG, Carrier MJ et al. Oenology: red wine procyanidins and vascular health. Nature . 2006;444(7119):566. Nov 30

2. Panagiotakos DB, Chrysohoou C, Siasos G, Zisimos K, Skoumas J, Pitsavos $\mathrm{C}$ et al. Sociodemographic and lifestyle statistics of oldest old people ( $>80$ years) living in ikaria island: the ikaria study. Cardiol Res Pract. 2011;2011:679187 https://doi.org/10.4061/2011/ 679187. Feb 24

3. Espinoza JL, Kurokawa Y, Takami A. Rationale for assessing the therapeutic potential of resveratrol in hematological malignancies. Blood Rev. 2018;pii: S0268-960X(17):30124-8. https://doi.org/10. 1016/j.blre.2018.07.001. Jul 5[Epub ahead of print] Review. PubMed PMID: 30005817

4. Theodorou A, Phylactides M, Forti L, Cramarossa MR, Spyrou P, Gambari $\mathrm{R}$ et al. The investigation of resveratrol and analogs as potential inducers of fetal hemoglobin. Blood Cells Mol Dis. 2016;58:6-12. https://doi.org/10.1016/j.bcmd.2015.11.007. May 